\title{
Assessment of groundwater quality for irrigation use in Alathur Block, Perambalur District, Tamilnadu, South India
}

\author{
A. Jafar Ahamed $\cdot$ S. Ananthakrishnan • \\ K. Loganathan · K. Manikandan
}

Received: 14 March 2013/Accepted: 14 August 2013/Published online: 31 August 2013

(C) The Author(s) 2013. This article is published with open access at Springerlink.com

\begin{abstract}
The suitability of groundwater for irrigation uses was assessed in Alathur Block located in Perambalur District of the state of Tamil Nadu. Groundwater samples from ten villages were analyzed in two seasons for major cations, anions and other parameters such as electrical conductivity, total dissolved solids, Kelly's ratio, sodium absorption ratio (SAR), magnesium ratio, \% sodium, chloro-alkaline indices, residual sodium carbonate and permeability index to know the suitability of groundwater for irrigation purpose. Piper trilinear diagram interpretations were made to know the suitability of chemical type of the groundwater. It reveals that the subsurface water is alkaline $(\mathrm{Na}+\mathrm{K})$ than the alkaline earth $(\mathrm{Ca}+\mathrm{Mg})$ type. According to the SAR values plotted in the USSL Staff diagram, most of the groundwater samples belong to class high-salinity hazard and low-sodium hazard $(\mathrm{C} 3-\mathrm{S} 1)$ and high-salinity hazard and medium-sodium hazard (C3-S2), which indicate that the groundwater of most stations require a special type of irrigation method.
\end{abstract}

Keywords Alathur - Correlation matrix - Groundwater . Irrigation water $\cdot$ Perambalur

A. Jafar Ahamed $(\bowtie) \cdot K$. Loganathan

PG and Research Department of Chemistry, Jamal Mohamed

College (Autonomous), Affiliated to Bharathidasan University,

Tiruchirappalli 620 020, Tamilnadu, India

e-mail: agjafar@yahoo.co.in

S. Ananthakrishnan

Department of Chemistry, Rover Engineering College,

Perambalur 621 212, Tamilnadu, India

K. Manikandan

Department of Chemistry, Velalar College of Engineering and

Technology, Erode 638 012, Tamilnadu, India

\section{Introduction}

Water is the cheapest and most universally available raw material next to air. Many of the uses of water are based on its unique physical and chemical properties. The utilizable water resource in India is not enough to irrigate the cultivatable area. Hence, efforts are needed to maximize the chances of water for irrigation in agriculture (Sharma 2005). The water quality is a consequence of the natural, physical and chemical state of the water as well as any alteration that might have accrued as a consequence of anthropogenic activity (Venkateswaran et al. 2011). Agriculture is a dominant sector in the economic development of India, as it is the source of sustenance for the majority of the population and contributes $46 \%$ of the gross national product (Kumarasamy et al. 2011). Groundwater is generally considered to be much cleaner than surface water. However, several factors such as discharge of industrial, agricultural and domestic water; land use practices; geological formation; rainfall patterns; and infiltration rate affect the groundwater quality (Patil and Patil 2010). Once contamination of groundwater in aquifers occurs, it persists for hundreds of years because of their very slow movement.

Geochemical processes in groundwater involve the interaction of country rock with water leading to the development of secondary mineral phases. In recent times, there has been a tremendous increase in the demand for freshwater due to population growth and intense agricultural activities (Janardhana Raju 2007). One of the interesting aspects of hydrochemistry is the occurrence of water bodies with different water chemistries in very close proximity to each other. The study of states reveals that countries like India and China are moving toward lack of available water and the problem will be compounded by issues of water quality (Shivakumar 2012). 
Irrigation is necessary for agricultural production in infertile and semiarid regions where rainfall is not sufficient to uphold crop growth. Irrigated agriculture consumes $60-80 \%$ of the total water usage and contributes nearly $38 \%$ of the global food production. It has played a major role in generating employment opportunities in the rural areas and providing food for low prices for downtrodden people in the urban area (Shahinasi and Kashuta 2008). There is no documented evidence of the chemical quality of the suitability of groundwater for irrigation purpose in this basin. In this paper, an attempt has been made to evaluate the quality of groundwater for irrigation purpose.

\section{Geology}

Perambalur is a centrally located inland district of the state of Tamil Nadu, India, spread over 3,69,007 ha. The net area under irrigation is 71,624 ha. Alathur is one of the major blocks in this district, which lies from $11^{\circ} 8^{\prime} 12.96^{\prime \prime}$ $\mathrm{N}, 78^{\circ} 41^{\prime} 31.16^{\prime \prime} \mathrm{E}$ to $11^{\circ} 04^{\prime} 36.35^{\prime \prime} \mathrm{N}, 78^{\circ} 61.65 .36^{\prime \prime} \mathrm{E}$ (Fig. 1). Gondwana group of rocks is locally developed that consists of clay, sandstone and micaceous sandstone, of age from Upper Jurassic to Lower Cretaceous. This rests unconformably above crystalline rocks. The above types of rocks are found in the area of Karai. The lower Kulakanatham Formation consists of calcareous sandstone and thin bands of shell limestone (http://www.portal.gsi.gov. in). The predominant soil is red loam and black soil. The normal rainfall of the district is $908 \mathrm{~mm}$ which is less than $946.4 \mathrm{~mm}$, the normal rainfall of the state. The annual rainfall during the northeast monsoon accounts for 52, $34 \%$ during the southwest monsoon and $14 \%$ in winter and hot weather periods. The groundwater resource is through bore well and tube well. The major crops grown in the district are paddy, groundnut, sugarcane and millets (http://www.perambalur.tn.nic.in/district_profile.htm).

\section{Materials and methods}

Groundwater samples were collected during the year 2012 in post-monsoon (January) and pre-monsoon (May) from ten bore wells which are almost uniformly distributed over the study area. The depth of the bore wells varies from 200 to $250 \mathrm{ft}$. Groundwater samples were analyzed in the laboratory for major cations and anions. $\mathrm{pH}$ and electrical conductivity (EC) were measured within a few hours by using Elico $\mathrm{pH}$ and conductivity meter, respectively. $\mathrm{Ca}^{2+}$ and $\mathrm{Mg}^{2+}$ were determined titrimetrically using the standard EDTA method, and chloride was determined by the $\mathrm{AgNO}_{3}$ titration (Vogel 1968) method. Bicarbonate was estimated with hydrochloric acid, and sulfate was determined by precipitating $\mathrm{BaSO}_{4}$ using $\mathrm{BaCl}_{2} \cdot \mathrm{Na}^{+}$and $\mathrm{K}^{+}$ were determined using Elico flame photometer (APHA 2005). To assess the suitability of groundwater for irrigation uses, the following irrigational quality parameters were computed by the following equations:

$\mathrm{SAR}=\frac{\mathrm{Na}^{+}}{\sqrt{\left(\mathrm{Ca}^{2+}+\mathrm{Mg}^{2+}\right) / 2}}$

$\% \mathrm{Na}=\frac{\left(\mathrm{Na}^{+}+\mathrm{K}^{+}\right) \times 100}{\sqrt{\left(\mathrm{Ca}^{2+}+\mathrm{Mg}^{2+}+\mathrm{Na}^{+}+\mathrm{K}^{+}\right)}}$

$\mathrm{PI}=\frac{\left(\mathrm{Na}^{+}+\sqrt{\mathrm{HCO}_{3}^{-}}\right)}{\sqrt{\left(\mathrm{Ca}^{2+}+\mathrm{Mg}^{2+} \mathrm{Na}^{+}\right)}} \times 100$

$\mathrm{CAI}-\mathrm{I}=\frac{\left(\mathrm{Cl}^{-}-\left(\mathrm{Na}^{+}+\mathrm{K}^{+}\right)\right)}{\mathrm{Cl}^{-}}$

$\mathrm{CAI}-\mathrm{II}=\frac{\left(\mathrm{Cl}^{-}-\left(\mathrm{Na}^{+}+\mathrm{K}^{+}\right)\right)}{\mathrm{SO}_{4}^{2-}+\mathrm{HCO}_{3}^{-}+\mathrm{CO}_{3}^{2-}+\mathrm{NO}_{3}^{-}}$

$\mathrm{RSC}=\left(\mathrm{CO}_{3}^{2-}+\mathrm{HCO}_{3}^{-}-\left(\mathrm{Ca}^{2+}+\mathrm{Mg}^{2+}\right)\right.$

$\mathrm{KR}=\frac{\mathrm{Na}^{+}}{\mathrm{Ca}^{2+}+\mathrm{Mg}^{2+}}$

$\mathrm{MR}=\frac{\mathrm{Mg}^{2+} \times 100}{\mathrm{Ca}^{2+}+\mathrm{Mg}^{2+}}$

All the ionic concentrations in the above equation are expressed in meq/L, and \% $\mathrm{Na}$ and $\mathrm{PI}$ in $\%$.

\section{Result and discussion}

It is very important to understand the quality of groundwater for various purposes, especially for irrigation. It is very unique, because the rainfall pattern constantly changes due to various factors. Since groundwater quality and quantity are very significant, various methods are applied to reveal the type of water which is discussed below.

\section{Groundwater chemistry}

The results of physico-chemical parameters and calculated irrigation water quality parameters are given in Table 1 .

In general, physico-chemical parameters vary seasonally because of rock salts leaching out from the earth crust. The run-off water alters the physico-chemical characteristics. The $\mathrm{pH}$ of groundwater samples in the study area ranges from 7.11 to 7.79 and 7.72 to 8.01 in post- and pre-monsoon season, respectively. Electrical conductivity in both the seasons exceeds the permissible limit of $1,000 \mu \mathrm{S} / \mathrm{cm}$ (WHO 2005). Total dissolved solid values varied between 687 to 3,796 and 873 to $3,497 \mathrm{mg} / \mathrm{L}$ in both the seasons. Except sample S6, all the samples are within the 
Fig. 1 Map of the study area
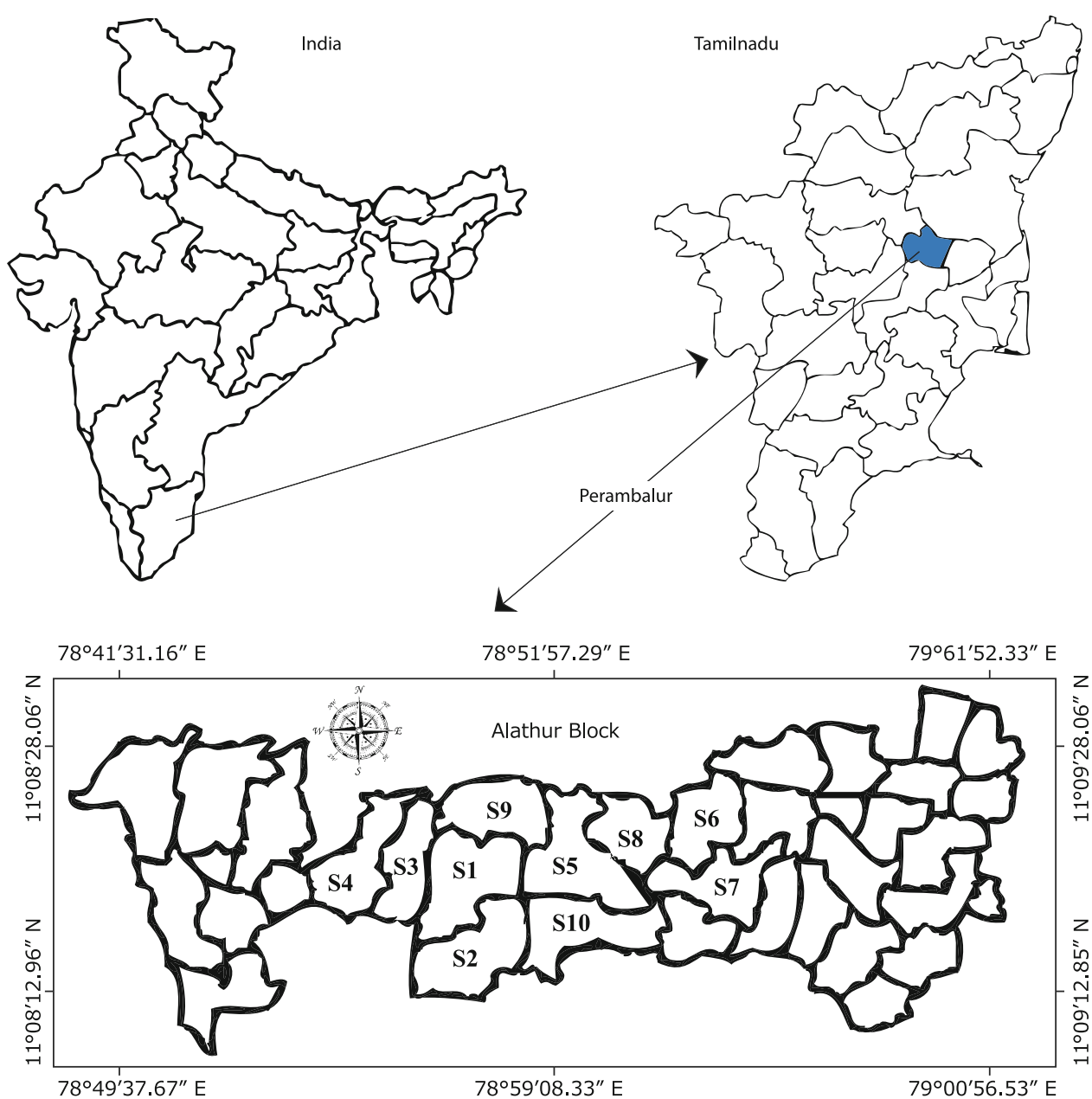

permissible limit of $1,500 \mathrm{mg} / \mathrm{L}$ (WHO 2005). The permissible limit for calcium and magnesium set by WHO (2005) is 200 and $150 \mathrm{mg} / \mathrm{L}$, respectively; samples from all the stations have well below this limit except sample S6. The concentration of fluoride is found to be low $(<1.0 \mathrm{mg} /$ L) in most of the samples. It indicates that minerals like topaz, fluorite, fluorapatite and cryolite type of rocks are absent in this study area. Concentrations of nitrate and phosphate are well within the WHO desirable limit of 45 and $1 \mathrm{mg} / \mathrm{L}$, respectively.

\section{Correlation analysis}

The correlation coefficient is generally used to measure and establish the relationship between two variables. It is simply used to exhibit how well one variable predicts the other (Kurumbein and Graybill 1965). The correlation matrix of various variables was prepared for post-monsoon and pre-monsoon (Table 2) and reveal that major parameters such as EC and total dissolved solids (TDS), EC and $\mathrm{Mg}, \mathrm{Ca}$ and TDS, and Mg and TDS exhibit high positive correlation with each other. There is a strong correlation value between $\mathrm{Cl}$ and $\mathrm{SO}_{4}^{2-}$ with $\mathrm{Ca}^{2+}$ and $\mathrm{Mg}^{2+}$. Almost all the ions show a negative relation with $\mathrm{pH}$ value. The above correlation shows that water belongs to the $\mathrm{Ca}-\mathrm{Mg}$ type with $\mathrm{Cl}-\mathrm{SO}_{4}$ anions. The correlation coefficient matrix is obtained by using SPSS software version 17.0 .

\section{Hydrochemical facies}

The geochemical evolution of groundwater can be obtained through Piper (1944) trilinear diagram during pre- and post-monsoon seasons as shown in Fig. 2. The diagram consists of three different fields, two triangular fields and one diamond-shaped field. Different groundwater types were identified by their position in the diamond field. In pre-monsoon seasons, most of the samples are identified as sodium-chloride $(\mathrm{Na}-\mathrm{Cl})$ type, while in post-monsoon season, the majority of the samples are in $\mathrm{Ca}-\mathrm{Mg}-\mathrm{HCO}_{3}$ and $\mathrm{Na}-\mathrm{Cl}$ type. Only one sample in both seasons falls under the calcium chloride $(\mathrm{Ca}-\mathrm{Cl})$ type. The above statement reveals that in both the seasons, water is mostly alkaline than alkaline earth. 


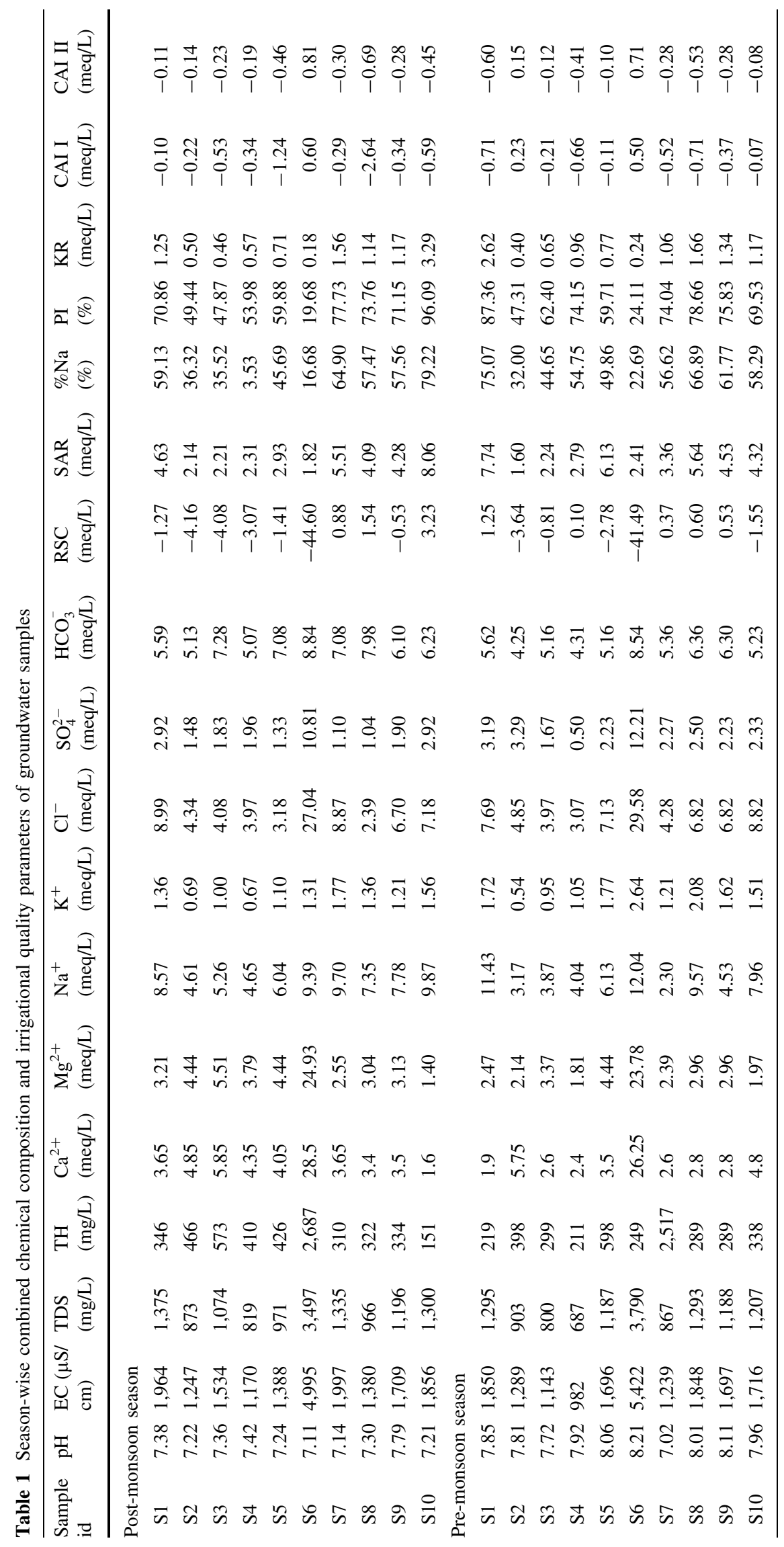


Table 2 Correlation matrix for different water quality parameters

\begin{tabular}{|c|c|c|c|c|c|c|c|c|c|c|c|c|c|c|}
\hline Parameters & $\mathrm{EC}$ & TDS & $\mathrm{pH}$ & $\mathrm{HCO}_{3}{ }^{-}$ & $\mathrm{TH}$ & $\mathrm{Ca}^{2+}$ & $\mathrm{Mg}^{2+}$ & $\mathrm{Na}^{+}$ & $\mathrm{K}^{+}$ & $\mathrm{NO}_{3}^{-}$ & $\mathrm{Cl}^{-}$ & $\mathrm{F}^{-}$ & $\mathrm{SO}_{4}^{2-}$ & $\mathrm{PO}_{4}^{-}$ \\
\hline \multicolumn{15}{|c|}{ Post-monsoon season } \\
\hline $\mathrm{EC}$ & 1 & & & & & & & & & & & & & \\
\hline TDS & 1.00 & 1 & & & & & & & & & & & & \\
\hline $\mathrm{pH}$ & -0.36 & -0.36 & 1 & & & & & & & & & & & \\
\hline $\mathrm{HCO}_{3}^{-}$ & 0.63 & 0.63 & -0.40 & 1 & & & & & & & & & & \\
\hline $\mathrm{TH}$ & 0.94 & 0.94 & -0.36 & 0.62 & 1 & & & & & & & & & \\
\hline $\mathrm{Ca}^{2+}$ & 0.94 & 0.94 & -0.36 & 0.62 & 1.00 & 1 & & & & & & & & \\
\hline $\mathrm{Mg}^{2+}$ & 0.93 & 0.93 & -0.36 & 0.62 & 1.00 & 1.00 & 1 & & & & & & & \\
\hline $\mathrm{Na}^{+}$ & 0.55 & 0.55 & -0.23 & 0.41 & 0.23 & 0.25 & 0.22 & 1 & & & & & & \\
\hline $\mathrm{K}^{+}$ & 0.31 & 0.31 & -0.26 & 0.47 & 0.00 & 0.01 & -0.01 & 0.92 & 1 & & & & & \\
\hline $\mathrm{NO}_{3}^{-}$ & 0.79 & 0.79 & -0.39 & 0.25 & 0.60 & 0.61 & 0.60 & 0.72 & 0.47 & 1 & & & & \\
\hline $\mathrm{Cl}^{-}$ & 0.99 & 0.99 & -0.34 & 0.52 & 0.91 & 0.92 & 0.90 & 0.56 & 0.30 & 0.83 & 1 & & & \\
\hline $\mathrm{F}^{-}$ & 0.77 & 0.77 & -0.07 & 0.14 & 0.65 & 0.66 & 0.64 & 0.45 & 0.19 & 0.77 & 0.82 & 1 & & \\
\hline $\mathrm{SO}_{4}^{2-}$ & 0.97 & 0.97 & -0.32 & 0.52 & 0.95 & 0.95 & 0.95 & 0.41 & 0.12 & 0.76 & 0.96 & 0.78 & 1 & \\
\hline $\mathrm{PO}_{4}^{-}$ & 0.17 & 0.17 & -0.28 & 0.62 & 0.06 & 0.07 & 0.06 & 0.45 & 0.62 & 0.08 & 0.11 & -0.18 & -0.01 & 1 \\
\hline \multicolumn{15}{|c|}{ Pre-monsoon season } \\
\hline $\mathrm{EC}$ & 1 & & & & & & & & & & & & & \\
\hline TDS & 1.00 & 1 & & & & & & & & & & & & \\
\hline $\mathrm{pH}$ & -0.85 & -0.85 & 1 & & & & & & & & & & & \\
\hline $\mathrm{HCO}_{3}^{-}$ & 0.90 & 0.90 & -0.64 & 1 & & & & & & & & & & \\
\hline TH & 0.97 & 0.97 & -0.90 & 0.81 & 1 & & & & & & & & & \\
\hline $\mathrm{Ca}^{2+}$ & 0.96 & 0.96 & -0.90 & 0.78 & 1.00 & 1 & & & & & & & & \\
\hline $\mathrm{Mg}^{2+}$ & 0.97 & 0.97 & -0.89 & 0.84 & 0.99 & 0.98 & 1 & & & & & & & \\
\hline $\mathrm{Na}^{+}$ & 0.71 & 0.71 & -0.42 & 0.80 & 0.52 & 0.49 & 0.55 & 1 & & & & & & \\
\hline $\mathrm{K}^{+}$ & 0.79 & 0.79 & -0.44 & 0.88 & 0.65 & 0.60 & 0.69 & 0.89 & 1 & & & & & \\
\hline $\mathrm{NO}_{3}^{-}$ & 0.77 & 0.77 & -0.42 & 0.88 & 0.61 & 0.59 & 0.62 & 0.89 & 0.84 & 1 & & & & \\
\hline $\mathrm{Cl}^{-}$ & 1.00 & 1.00 & -0.85 & 0.88 & 0.97 & 0.97 & 0.97 & 0.69 & 0.77 & 0.74 & 1 & & & \\
\hline $\mathrm{F}^{-}$ & 0.39 & 0.39 & -0.38 & 0.48 & 0.41 & 0.40 & 0.42 & 0.24 & 0.10 & 0.34 & 0.38 & 1 & & \\
\hline $\mathrm{SO}_{4}^{2-}$ & 0.98 & 0.98 & -0.88 & 0.84 & 0.98 & 0.97 & 0.97 & 0.62 & 0.67 & 0.72 & 0.97 & 0.48 & 1 & \\
\hline $\mathrm{PO}_{4}^{-}$ & 0.32 & 0.32 & -0.14 & 0.33 & 0.25 & 0.25 & 0.24 & 0.41 & 0.57 & 0.34 & 0.31 & -0.47 & 0.20 & 1 \\
\hline
\end{tabular}

Suitability for irrigation use

\section{Total dissolved solids (TDS)}

For irrigation purpose, the quality of water depends on the quantity of dissolved salts. Salinity problem occurs if salt accumulates in the root zone, which may significantly affect the quantity of crop production (Jain et al. 2011). If water uptake is appreciably reduced, the plant growth rate is also reduced. Water with TDS less than $450 \mathrm{mg} / \mathrm{L}$ is considered good and that with greater than $2,000 \mathrm{mg} / \mathrm{L}$ is unsuitable for agricultural purposes (Westcott and Ayers 1984). In our study area, TDS ranges from 687 to $3796 \mathrm{mg} /$ $\mathrm{L}$ during the pre-monsoon season. It varies from 873 to $3497 \mathrm{mg} / \mathrm{L}$ in the post-monsoon season.

\section{Electrical conductivity (EC)}

Water salinity hazards are measured by using EC. If EC is greater than $3,000 \mu \mathrm{S} / \mathrm{cm}$, then crop productivity is affected very much, and it is good if EC is $250 \mu \mathrm{S} / \mathrm{cm}$ (Westcott and Ayers 1984). If EC increases, water intake by the plant significantly decreases and, hence, the productivity is also considerably reduced. In our study area, EC varies from 982 to $5,422 \mu \mathrm{S} / \mathrm{cm}$ during the pre-monsoon season and 1,170 to $3,495 \mu \mathrm{S} / \mathrm{cm}$ in the post-monsoon season. Most of the samples having EC greater than $250 \mu \mathrm{S} / \mathrm{cm}$ show moderate-to-low crop productivity in both the seasons. The difference between the values may reflect a wide variation in surface and subsurface environments (Amidi and Amidi 1990). 


\section{Sodium adsorption ratio (SAR) and USSL diagram}

The excessive sodium content in water sample reduces the permeability, and hence, the available water for the plant is reduced. Sodium replacing adsorbed calcium and magnesium is a hazard, as it causes damage to the soil structure resulting in compact and impervious soil (Arveti et al. 2011). The excess of sodium with calcium and magnesium is evaluated by SAR. Irrigation water is classified on the basis of SAR (WHO 1989). In both the seasons, all the ten samples were in excellent condition. US salinity hazards (USSL 1954) reveal that for water samples in the Alathur Block, most fall under C3-S1 (high-salinity hazard and low-sodium hazard) class and some of them in the C3-S2 (high-salinity hazard and medium-sodium hazard) class, while one sample fell in C4-S1 (Very high-salinity hazard and low-sodium hazard) class in both the seasons (Fig. 3). Groundwater that is present in the medium-salinity hazard class (C2) can be used in most cases without any special practices for salinity control. The groundwater observed from the zone C3-S1 and $\mathrm{C} 3-\mathrm{S} 2$ is considered to be of moderate quality to irrigate semi-tolerant crops. However, water samples that fall in the high-salinity areas require careful management practices. Very high-salinity water (C4) is not suitable for irrigation

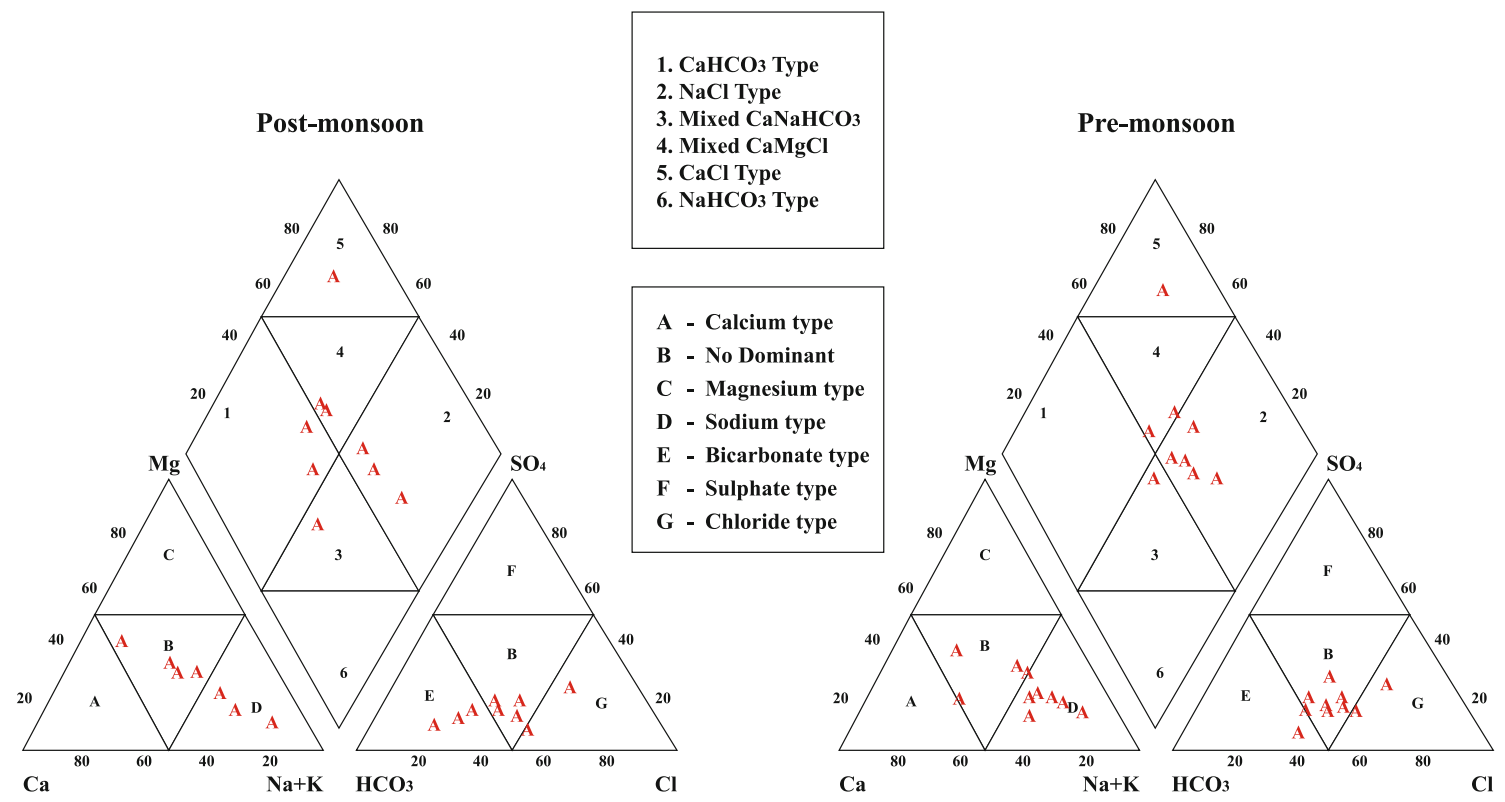

Fig. 2 Piper trilinear diagram for post-monsoon season and pre-monsoon season
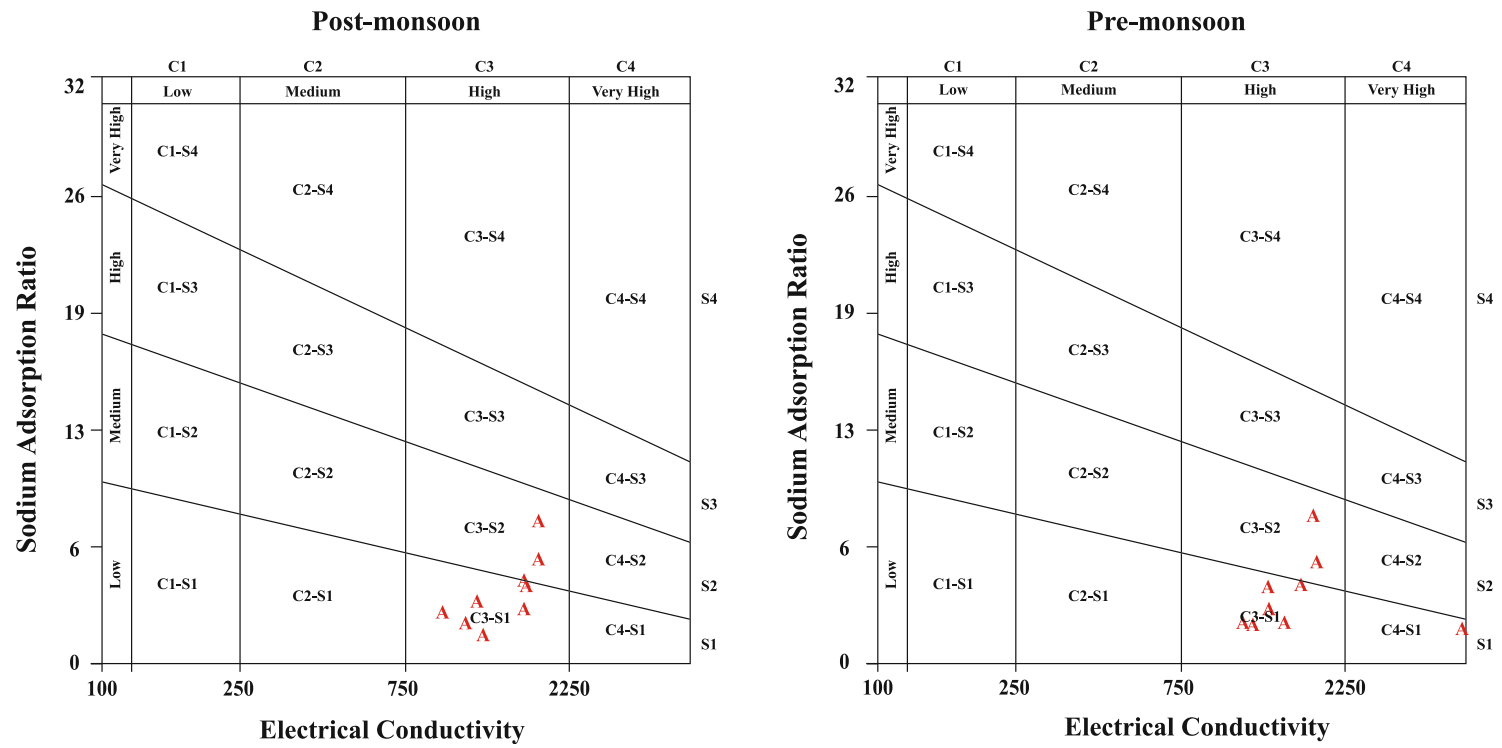

Fig. 3 US salinity diagram for post-monsoon season and pre-monsoon season 
under ordinary condition, but it may be used for salt-tolerant plant on permeable soil with special management practice (Khodapanah et al. 2009).

\section{Percent sodium (\% $\mathrm{Na}$ ) and Wilcox diagram}

For irrigation purpose, the percentage of sodium is important, because sodium reacts with soil to reduce permeability (Janardhana Raju et al. 1992). The soluble sodium percentage or sodium content is expressed in terms of percentage of sodium. \% Na ranges from 32 to $75.5 \%$ in the pre-monsoon season and from 3.5 to 79.5 in the postmonsoon season. The plot of the Wilcox (1948) diagram shows that in the pre-monsoon season, $70 \%$ samples fall under permissible-to-doubtful range, $10 \%$ in permissibleto-suitable and $10 \%$ in good-to-permissible range (Fig. 4). Post-monsoon season shows that $40 \%$ of the samples are in good-to-permissible range, $40 \%$ in permissible-todoubtful range, $10 \%$ in permissible-to-unsuitable and $10 \%$ in unsuitable range as shown in the Fig. 4. The presence of excess of sodium causes most of the samples to be in the permissible-to-doubtful ranges and restrict air and water circulation in the soil during the wet condition (Collins and Jerkins 1996; Saleh et al. 1999).

\section{Permeability index (PI)}

Continuous usage of water for irrigation will affect the permeability quality of the soil. It is influenced by $\mathrm{Na}$,
$\mathrm{Ca}, \mathrm{Mg}$ and $\mathrm{HCO}_{3}$ contents in soil. Doneen (1964) has shown the suitability of water for irrigation based on the permeability index (PI). According to PI values, the groundwater of both seasons in the study area in most of the stations falls under class II $(25-75 \%)$. All the samples fall in class II, except that samples from three stations in the pre-monsoon and two in the post-monsoon fall under class I $(>75 \%)$ as classified by (Ragunath 1982) on the basis of USSL diagram and Donnen's chart. The groundwater in our study area is generally suitable for irrigation.

\section{Chloro-alkaline indices (CAI)}

Finding out the changes brought about in the chemical composition of groundwater during its travel underground is essential (Sastri 1994). The ion exchange between the groundwater and its environment during residence or travel has been studied by Schoeller (1967). In both seasons, most of the samples have negative values except one which shows a positive value. If CAI is negative, there will be an exchange between $\mathrm{Na}+\mathrm{K}$ with calcium and magnesium $(\mathrm{Ca}+\mathrm{Mg})$ in rocks. If the ratio is positive, there is no base change in CAI. Most of the values in CAI I are negative and one value is positive in both the seasons. The positive value indicates the absence of base exchange. The negative value of the ratio indicates base exchange between sodium and potassium in water with calcium and magnesium in the rocks.
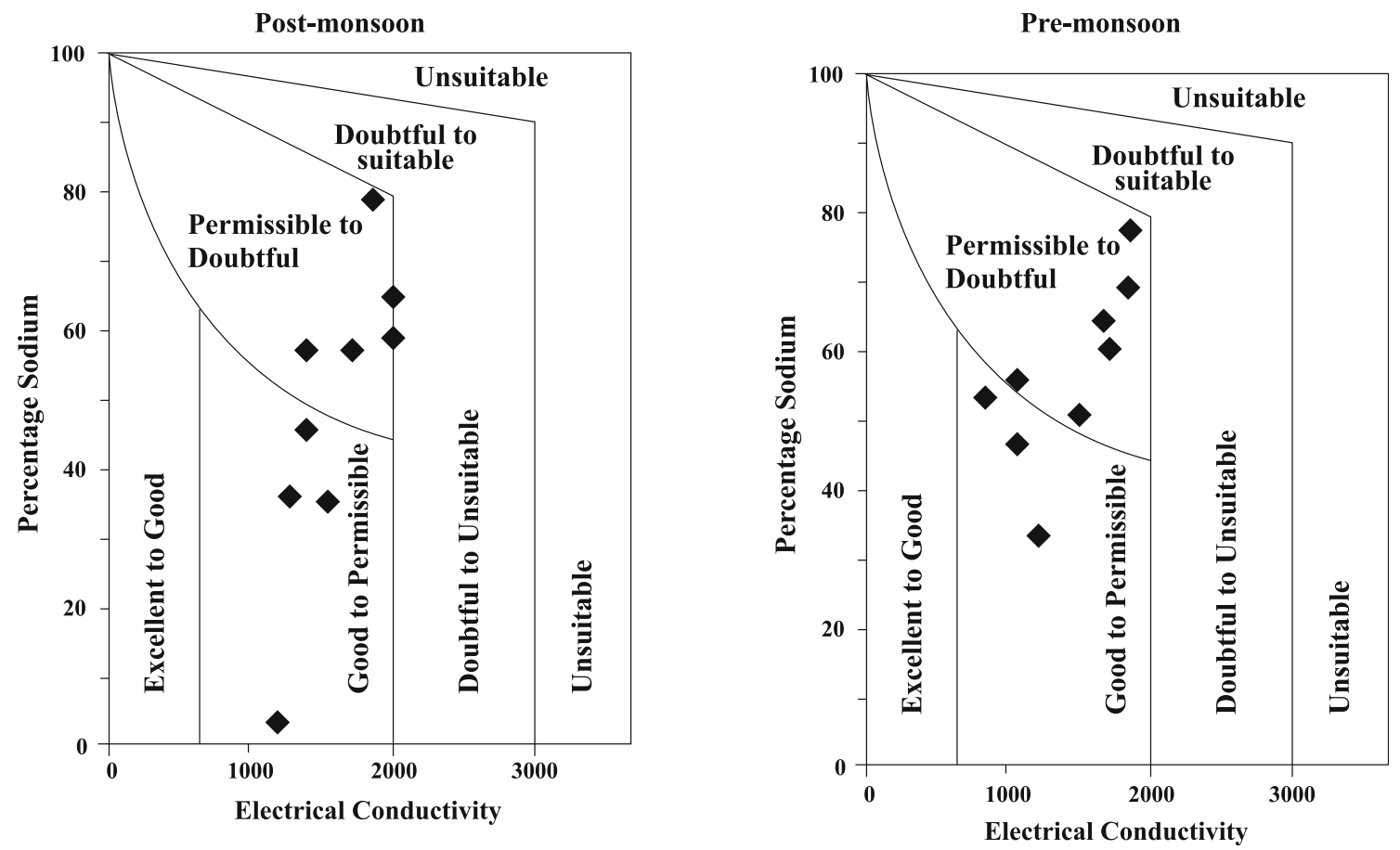

Fig. 4 Suitability of groundwater for irrigation in Wilcox diagram for post-monsoon and pre-monsoon season

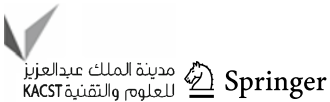




\section{Residual sodium carbonate (RSC)}

RSC values were calculated to determine the hazardous effect of $\mathrm{CO}_{3}$ and $\mathrm{HCO}_{3}$ on the water quality for agricultural purpose (Eaton 1950; Richards 1954). According to USSL diagram, an RSC value $<1.25 \mathrm{meq} / \mathrm{L}$ is probably safe for irrigation. If it is $>2.5 \mathrm{meq} / \mathrm{L}$, it is not suitable for irrigation. In our study area, in post-monsoon, $80 \%$ places were safe, $10 \%$ of places are marginal and $10 \%$ are unsuitable. In the pre-monsoon season, all the values fall in the safe zone. These studies show that one sample is unsuitable for irrigation, because of the low permeability of the soil during the post-monsoon season. This shows that there must be localized and seasonal pollution which reduce the crop yield in that area.

\section{Kelley's ratio $(K R)$}

(Kelly 1951) has suggested that the sodium problem in irrigation water could be very conveniently worked on the basis of the values of Kelly's ratio. In general, groundwater with Kelly's ratio greater than one is unfit for irrigation. Kelly's ratio is calculated for our study area which ranges from 0.25 to $2.14 \mathrm{meq} / \mathrm{L}$ in the post-monsoon season, whereas it is 0.34 to $3.87 \mathrm{meq} / \mathrm{L}$ in the pre-monsoon season. The stations that have more than one of Kelly's ratio are unfit for irrigation.

\section{Magnesium ratio $(M R)$}

Excess of magnesium in the soil easily affects the crop yield. In both the seasons, magnesium value is greater than the permissible limit except few stations and ranges from 18.14 to $14.12 \mathrm{meq} / \mathrm{L}$ in the pre-monsoon and 29.81 to $40.00 \mathrm{meq} / \mathrm{L}$ in the post-monsoon season. MR $>50$ is considered harmful and unsuitable for irrigation purposes. High magnesium ratio may be due to the passage of surface water and subsurface water through limestone, Kankar and granite rock formation in the study area (Pandian and Sankar 2007).

\section{Conclusion}

In the present study, the assessment of groundwater for irrigation has been evaluated by the standard guidelines. Piper trilinear diagram interpretation reveals that the subsurface water is alkaline $(\mathrm{Na}+\mathrm{K})$ in nature which exceeds the alkaline earth $(\mathrm{Ca}+\mathrm{Mg})$ type. Most of the samples fall under Class II in PI calculation, revealing that most of the stations are suitable for irrigation. The Wilcox classification as observed in both the seasons shows that samples from most of the stations fall under permissible-to-doubtful range except the that from station Siruganbur which is not suitable for irrigation under ordinary conditions. USSL diagram also reveals that most of the stations show highsalinity hazards where Siruganbur does not fall into any of the classes. The study reveals that most of the stations require special type of irrigation methods to control the high salinity that will improve the yield of crop production.

Acknowledgments The author thank the members of the Management Committee and the Principal of Jamal Mohamed College for providing necessary fund and facilities.

Open Access This article is distributed under the terms of the Creative Commons Attribution License which permits any use, distribution, and reproduction in any medium, provided the original author(s) and the source are credited.

\section{References}

Amidi UMP, Amidi PA (1990) Salt water migration in the coastal aquifers of southern Nigeria. J Min Geol 26:35-44

APHA (2005) Standard Methods for the Examination of Water and Wastewater, 21st edn. American Public Health Association, Washington DC

Arveti N, Sarma MRS, Aitkenhead-Peterson JA, Sunil K (2011) Fluoride incidence in groundwater: a case study from Talupula, Andhra Pradesh, India. Environ Monit Asses 172:427-443

Collins R, Jerkins A (1996) The impact of agriculture land use on stream chemistry in the middle Hills of the Himalayas, Nepal. J Hydrol 185:71-86

Doneen LD (1964) Notes on water quality in Agriculture Published as a Water Science and Engineering Paper 4001, Department of Water Science and Engineering, University of California

Eaton FM (1950) Significance of carbonate irrigation water. Soils Sci 69(2):123-133

Jain MK, Dadhich LK, Kalpana S (2011) Water quality assessment of Kishanpura Dam, Baran, Rajasthan, India. Nat Environ Poll Tech 10:405-408

Janardhana Raju N (2007) Hydrogoechemical parameters for assessment of groundwater quality in the upper Gunjanaeru River basin, Cuddapah District, Andhra Pradesh, South India. Eviron Geol 52:1067-1074

Janardhana Raju N, Reddy TVK, Kotaiah B, Nayudu PT (1992) A study on seasonal variations of ground water quality in upper Gunjanaeru River basin, Cuddapah District, Andhra Pradesh. Fresenius Environ Bull 1:98-103

Kelly VP (1951) Alkali Soils: their formation properties and reclamations. Reinhold, New York

Khodapanah L, Sulaiman WNA, Khodapanah N (2009) Groundwater quality assessment for different purposes in Eshtehard District, Tehran, Iran. Eur J Sci Res 36:543-553

Kumarasamy P, Alaguraja P, Deepasaraswathi M, Sekar M, Muthuveerran P, Yuvaraj D, Thirunavukkarasu A, Arthur J, Sames R (2011) Soil suitability and water quality study in Tirupur areas using geographic information system techniques. Int J Earth Sci Eng 4:85-97

Kurumbein WC, Graybill FA (1965) An introduction to statistical models in geology. McGraw-Hill, New York

Pandian K, Sankar K (2007) Hydrogeochemistry and groundwater quality in the Vaippar River basin, Tamilnadu. J Geo Sci Ind 69:970-982 
Patil VT, Patil PR (2010) Suitability assessment of groundwater for irrigation and drinking purpose in the northern region of Jordan. J Environ Sci Tech 5:274-290

Piper AM (1944) A graphical procedure in the geochemical interpretation of water analysis. Am Geophys Union Trans 25:914-928

Ragunath HM (1982) Groundwater. Wiley Eastern Limited, New Delhi 456

Richards LA (1954) Diagnosis and improvement of saline alkali soils: Agriculture. Handbook, US department of Agriculture, Washington DC, 160:60

Saleh A, Al-Ruwaith F, Shehata M (1999) Hydrogeochemical process operating within the main aquifers of Kuwait. J Arid Environ 42:195-209

Sastri JCV (1994) Groundwater chemical quality in river basin. Hydrogeochemical facies and hydrogeochemical modeling. Lecture notes-Refresher course conducted by school of Earth Science. Bharathidasan University. Trichirapalli, Tamilnadu, India

Schoeller H (1967) Qualitative evaluation of ground water resources. In: Methods and techniques of groundwater investigation and development. Water Research Series-33, UNESCO, pp 44-52

Shahinasi E, Kashuta V (2008) Irrigation water quality and its effects upon soil. Tirana Agricultural University, Tirana, Albania BALWOIS 2008, Ohrid, Rebublic of Macedonia
Sharma BK (2005) Water pollution, 4th edn. Goel Publishing House, Meerut

Shivakumar C (2012) Taps to go dry in 20 years. The New Indian Express, Trichy

US Salinity Laboratory (1954) Diagnosis and improvement of saline and alkaline soils. Agriculture Handbook No. 60 USDA, p 160

Venkateswaran S, Vijay Prabhu M, Mohammed Rafi M, Vallel LK (2011) Assessment of groundwater quality for irrigational use in Cumbum Valley, Madurai District, Tamil Nadu, India. Nat Environ Poll Tech 10:207-212

Vogel AI (1968) A Text Book of Quantitative Inorganic Analysis Including Elementary Instrumental Analysis. 3rd edn. ELBS/ Longman, p 121

Westcott DW, Ayers RC (1984) Water quality criteria in irrigation with Reclaim municipal wastewater: state water resources control board Sacramento, California

WHO (1989) Health Guidelines for the Use of Wastewater in Agriculture and Aqua culture. Report of a WHO Scientific Group-Technical Report Series 778, WHO Geneva, p 74

WHO (2005) International standards for drinking water. World Health Organization, Geneva

Wilcox LV (1948) The quality of water for irrigation use. US Department of Agriculture Technology Bulletin 962, Washington DC 